\title{
IRS proteins and diabetic complications
}

\author{
Deborah P. Lavin ${ }^{1} \cdot$ Morris F. White ${ }^{2}$ Derek P. Brazil ${ }^{1}$
}

Received: 15 June 2016 / Accepted: 8 July 2016 / Published online: 11 August 2016

(C) The Author(s) 2016. This article is published with open access at Springerlink.com

\begin{abstract}
IRS proteins are cellular adaptor molecules that mediate many of the key metabolic actions of insulin. When tyrosine is phosphorylated by the activated insulin receptor, IRS proteins recruit downstream effectors, such as phosphoinositide 3-kinase and mitogen-activated protein kinase, in order to elicit cellular responses such as glucose uptake, lipid metabolism and cell proliferation. There are two main IRS proteins in humans (IRS1 and IRS2), both of which are widely expressed. Given their central role in the insulin signalling pathway, it is not surprising that male mice lacking Irs 1 or Irs 2 present with elevated blood glucose or type 2 diabetes, respectively. For reasons yet to be identified, female $\operatorname{Irs} 2^{-/-}$mice do not develop type 2 diabetes. A number of organs are affected by complications of diabetes; macrovascular complications include stroke and coronary artery disease, while nephropathy, neuropathy and retinopathy fall into the category of microvascular complications. Given the serious consequences of these complications on patient morbidity and mortality, it is essential to identify the molecular pathogenesis underlying diabetic complications, with a view to improving therapeutic intervention and patient outcomes. A number of recently published papers have converged on the hypothesis that the loss of insulin signalling and IRS proteins is instrumental to the development and/or progression of diabetic
\end{abstract}

Derek P. Brazil

d.brazil@qub.ac.uk

1 Centre for Experimental Medicine, School of Medicine, Dentistry and Biomedical Sciences, Queen's University Belfast, 97 Lisburn Road, Belfast BT9 7BL, Northern Ireland, UK

2 Division of Endocrinology, Children's Hospital Boston, Harvard Medical School, Boston, MA, USA complications. This review will summarise some highlights from the published work in which this hypothesis is discussed.

Keywords Diabetic complications · Eye $\cdot$ Heart · Insulin · Insulin receptor substrate $\cdot$ Kidney $\cdot$ Neuron $\cdot$ Review

$\begin{array}{ll}\text { Abbreviations } \\ \text { ApoE } & \text { Apolipoprotein E } \\ \text { CAD } & \text { Coronary artery disease } \\ \text { CVD } & \text { Cardiovascular disease } \\ \text { ESRD } & \text { End-stage renal disease } \\ \text { eNOS } & \text { Endothelial nitric oxide synthase } \\ \text { ET-1 } & \text { Endothelin-1 } \\ \text { GBM } & \text { Glomerular basement membrane } \\ \text { GLP-1 } & \text { Glucagon-like peptide-1 } \\ \text { GSK3 } \beta & \text { Glycogen synthase kinase } 3 \beta \\ \text { HIF-2 } \alpha & \text { Hypoxia-inducible factor-2 } \alpha \\ \text { HO-1 } & \text { Haemoxygenase-1 } \\ \text { IGF-1R } & \text { IGF-1 receptor } \\ \text { IGFBP-2 } & \text { IGF binding protein } 2 \\ \text { IR } & \text { Insulin receptor } \\ \text { Ikk } \beta & \text { Inhibitor of nuclear factor k-B kinase subunit } \beta \\ \text { JAK2 } & \text { Janus kinase } 2 \\ \text { JNK } & \text { c-Jun N-terminal kinase } \\ \text { MI } & \text { Myocardial infarction } \\ \text { mTORC } & \text { Mammalian target of rapamycin complex } \\ \text { MAPK } & \text { Mitogen-activated protein kinase } \\ \text { PAI-1 } & \text { Plasminogen activator inhibitor-1 } \\ \text { PH } & \text { Pleckstrin homology } \\ \text { PI3K } & \text { Phosphoinositide 3-kinase } \\ \text { PKB } & \text { Protein kinase B/Akt } \\ \text { PKC } \beta & \text { Protein kinase C } \beta \\ \text { PodIRKO } & \text { Podocyte-specific Insr-knockout } \\ & \end{array}$




\begin{tabular}{|c|c|}
\hline $\operatorname{PPAR} \gamma$ & Peroxisome proliferator-activated receptor- $\gamma$ \\
\hline PTB & Phosphotyrosine binding \\
\hline SNP & Single-nucleotide polymorphism \\
\hline STAT3 & $\begin{array}{l}\text { Signal transducer and activator of } \\
\text { transcription } 3\end{array}$ \\
\hline STZ & Streptozotocin \\
\hline VCAM-1 & Vascular cell adhesion molecule-1 \\
\hline VEGF & Vascular endothelial growth factor \\
\hline
\end{tabular}

Highlights
- IRS proteins and cardiovascular disease
- IRS proteins and diabetic nephropathy
- IRS proteins in diabetic retinopathy
- IRS proteins in the brain
- IRS proteins in diabetic neuropathy

\section{Introduction}

Insulin and IGF signalling require a family of scaffold proteins (IRS proteins) to integrate extracellular signals into intracellular responses, leading to cellular effects. There are two main IRS proteins in humans, IRS1 and IRS2, which are widely expressed in most human (and mammalian) tissues, whilst a third protein, IRS4, is mainly expressed in the hypothalamus [1]. All IRS proteins consist of an amino terminal pleckstrin homology (PH) domain and a phosphotyrosine binding (PTB) domain, followed by a long tail of tyrosine residues that act as phosphorylation sites to drive insulin/IGF-1 signalling [2]. IRS proteins can also be phosphorylated on Ser and Thr residues, and the majority of evidence suggests that this leads to reduced IRS protein expression and attenuated insulin signalling. Although similar in structure and sequence, the IRS proteins possess distinct roles in mammalian physiology. This is beautifully illustrated by the phenotypes of Irs1- vs Irs2knockout mice. Male mice lacking Irs 1 have a small body size, and increased beta cell mass accompanied by mild metabolic defects [3, 4]. In contrast, male Irs $2^{-/-}$mice are normal in size but develop diabetes at around 8 weeks, due to hepatic and peripheral insulin resistance and pancreatic beta cell insufficiency $[3,5]$. The primary signalling pathway activated by IRS proteins is the phosphoinositide 3-kinase (PI3K)-protein kinase $\mathrm{B}(\mathrm{PKB} / \mathrm{Akt})$ cascade, which regulates many downstream effectors such as glycogen synthase kinase $3 \beta$ $($ GSK $3 \beta)$, mammalian target of rapamycin complex 1 (mTORC1) and mTORC2, and Forkhead transcription factors [2]. Changes in IRS protein function have been well studied in diabetes, in mouse models and human samples. This review will summarise a wealth of data describing the role of IRS proteins in diabetic complications, many of which may involve altered insulin and IGF-1 signalling as causal factors.

\section{IRS proteins and cardiovascular disease}

Diabetes significantly increases the risks of cardiovascular disease (CVD). In the UK, CVD accounts for $48 \%$ of fatalities in people with either type 1 or type 2 diabetes [6,7]. The risk of stroke, angina, myocardial infarction (MI) and heart failure is approximately double in diabetic patients. Intensive control of blood glucose has been shown to decrease the risk of non-fatal heart attack, stroke or death from CVD by $57 \%$ in diabetic patients [8]. Insulin has been proposed to mediate an antiatherogenic effect on blood vessels via IRS-PI3K-Akt signalling [9]. This leads to activation of endothelial nitric oxide synthase (eNOS), expression of haemoxygenase-1 (HO-1) and vascular endothelial growth factor (VEGF) and decreased expression of vascular cell adhesion molecule-1 (VCAM-1), all of which are protective against vascular damage [9]. In contrast, insulin-mediated activation of growth factor receptor bound protein-2 / SH2-containing proto-oncogene / mitogenactivated protein kinase (MAPK) mediates a pro-atherogenic effect, increasing expression of endothelin-1 (ET-1) and plasminogen activator inhibitor-1 (PAI-1) and increasing the proliferation of contractile cells in the blood vessels [9]. In diabetes, which is characterised by an absence of insulin or increased peripheral insulin resistance (or both), a reduction in insulin receptor (IR) to IRS to PI3K to Akt signalling leads to acceleration of atherosclerosis because of the loss of anti-atherogenic insulin signalling [9]. Angiotensin II, NEFA and TNF- $\alpha$ contribute to this effect by increasing serine phosphorylation of IRS proteins, which leads to decreased Akt activation, reduced VEGF expression and poorer outcomes in CVD [9]. Protein kinase $\mathrm{C} \beta$ (PKC $\beta$ ) isoforms such as $\mathrm{PKC} \beta 2$ have been implicated in IRS2 phosphorylation on Ser303 and Ser675, leading to negative regulation of IRS2 tyrosine phosphorylation and reduced insulin signalling [10]. In addition, PKC inhibitors such as ruboxistaurin have been shown to reduce the severity of myocardial injury in rodent models of diabetic heart disease [11-13] and in a pig model of MI [14].

The essential role of insulin in healthy heart and blood vessel function has been highlighted by studies in which the IR was deleted from cardiac muscle and endothelial cells. Mice lacking IR expression in cardiac muscle (MIRKO) showed impaired cardiac performance at 6 months [15]. When these MIRKO mice had a single copy of Igfrl deleted, they died within 4 weeks of birth due to dilated cardiomyopathy [15]. Similarly, endothelial cell-specific Insr-knockout mice (EIRKO) displayed accelerated atherosclerosis when crossed with apolipoprotein E (ApoE) null mice [16]. Analysis of left ventricular myocardial biopsies from humans with type 1 diabetes showed a surprising increase in IR to 
IRS1 to PI3K to Akt signalling [17]. These changes were accompanied by a decrease in GLUT4 expression in the sarcolemma, suggesting defective myocardial insulin resistance in type 1 diabetes. This hypothesis is supported by data from the $o b / o b$ model of type 2 diabetes, which, along with other data from animal models, is shown in Table 1.

Data from human studies Several epidemiological studies have identified polymorphisms that implicate IRS proteins in the incidence of diabetic complications. A specific Gly(972)Arg substitution mutation in the IRS1 gene is a significant independent predictor of coronary artery disease (CAD) [18]. IRS1 Gly(972)Arg mutations were detected in $6.8 \%$ of control and $18.9 \%$ of individuals with coronary atherosclerosis identified by angiography [18]. The IRSI Gly(972)Arg mutation was associated with an increased risk of CAD, independent of other factors such as smoking or hypertension, with an additional increase in risk in obese individuals or those with insulin resistance syndrome [18]. Diabetes incidence and plasma triacylglycerol levels are increased in CAD Gly(972)Arg mutation carriers compared with non-carriers [18]. Interestingly, IRSI Gly(972)Arg mutations were observed in $5.8 \%$ of the general population and $10.7 \%$ of individuals with type 2 diabetes, suggesting a genetic basis for increased CAD in the diabetic population [19].

A meta-analysis of 27 studies, carried out by Jellema et al, showed that IRS1 Gly(972)Arg carriers had a 25\% greater risk of developing type 2 diabetes [20]. Liu et al showed that the IRS1 Gly(972)Arg mutation associates with serum ACE2 levels in patients following acute MI [21]. ACE2 was significantly elevated in acute MI patients vs control; however IRSI Gly(972)Arg carriers with acute MI had significantly decreased levels of ACE2, presenting with a more severe MI and a poorer prognosis [21]. As ACE2 negatively regulates the renin-angiotensin system, it has a cardioprotective role following its activation post MI and counteracts the adverse cardiac reninangiotensin system effects [21]. In the presence of insulin, and under hypoxic conditions in vitro, IRS1 Gly(972)Arg inhibited ACE2 expression in human cardiomyocytes, revealing a possible link between insulin and IRS protein signalling and cardiac renin-angiotensin system activation [21]. Another case-control study has supporting data from subjects of Punjabi origin, where IRS1 Gly(972)Arg carriers or Arg homozygous individuals had a higher risk of CAD in the overall population [22]. However, contradictory data from a case-control study by Strohmer et al showed no association between the Gly(972)Arg mutation and CAD in male or female patients, or in obese patients, in the Austrian population, although the power of this study required to determine a causal role was suboptimal [23]. Data from Vats et al have shown that a single-nucleotide polymorphism (SNP) in IRS2 - Gly(1057)Asp - is also associated with CAD, where Gly(1057)Asp carriers or Asp1057 homozygous individuals have an increased risk of developing CAD in the overall population of Punjabi origin, and in obese individuals [22]. Chan et al have shown that in the Taiwanese population, IRS2 Gly1057 homozygous/heterozygous individuals are at increased risk of developing CAD, whereas Asp/

Table 1 Summary of data linking IRS proteins to cardiac dysfunction

\begin{tabular}{|c|c|c|c|c|}
\hline $\begin{array}{l}\text { IRS } \\
\text { involved }\end{array}$ & Mouse model & $\begin{array}{l}\text { Organ } \\
\text { affected }\end{array}$ & Main findings & Reference \\
\hline \multirow[t]{2}{*}{ IRS1, IRS2 } & $\begin{array}{l}\text { Myocardium-specific } \\
\quad \operatorname{Irs} 1^{-/-} ; \operatorname{Irs} 2^{-/-} \text {mice }\end{array}$ & Heart & $\begin{array}{l}\text { In the absence of both } \operatorname{Irs} 1 \text { and } \operatorname{Irs} 2 \text {, thinning walls, global dilatation, } \\
\text { diastolic failure and decreased systolic activity were evident. Heart } \\
\text { failure markers such as } \beta \text {-myosin heavy chain increased and } \\
\text { interstitial fibrosis was associated with increased TGF } \beta 1 \text { and } \\
\text { collagen } 1 \text { mRNA. Myocardium-specific } \operatorname{Irs} 1^{-/-} ; \operatorname{Irs} 2^{-/-} \text {mice died at } \\
6-8 \text { weeks of age, yet heterozygous myocardium } \operatorname{Irs} 1^{+/-} ; \operatorname{Irs} 2^{+/-} \\
\text {mice survived to at least } 6 \text { months of age before fatal cardiac } \\
\text { dysfunction developed }\end{array}$ & Qi et al (2013) [78] \\
\hline & $\begin{array}{r}\text { Mice with specific hepatic } \\
\text { deletion of Irs } 1 \text { and Irs } 2\end{array}$ & Liver & $\begin{array}{l}\text { Hepatic deletion of Irs } 1 \text { and Irs } 2 \text { caused a decrease in cardiac IRS1 and } \\
\text { IRS2, and similar, albeit less severe, effects on the heart were observed. } \\
\text { These mice showed p38MAPK activation, which mediated IRS protein } \\
\text { degradation in response to chronic insulin stimulation. These data } \\
\text { suggest a new link between hepatic insulin signalling and IRS protein } \\
\text { levels in the heart }\end{array}$ & Qi et al (2013) [78] \\
\hline IRS1 & $\begin{array}{l}o b / o b \text { mice (model of } \\
\text { type } 2 \text { diabetes) }\end{array}$ & Heart & $\begin{array}{l}\text { Myocardial IRS1-PI3K activity was significantly increased in } o b / o b \text { mice } \\
\text { vs control. These data were similar to IRS1-PI3K activity in both } \\
\text { individuals with type } 2 \text { diabetes and those with left ventricular dysfunction, } \\
\text { whose myocardium was insulin resistant. IR- } \beta \text {, IRS1 and total and } \\
\text { phospho-Akt were also increased in } o b / o b \text { mice; however, total IRS1 } \\
\text { was unchanged in individuals with type } 2 \text { diabetes and left ventricular } \\
\text { dysfunction. Insulin-induced Akt phosphorylation was greater in control } \\
\text { mice than in } o b / o b \text { mice with no alterations in total Akt }\end{array}$ & $\begin{array}{l}\text { Cook et al } \\
\qquad(2010)[17]^{\mathrm{a}}\end{array}$ \\
\hline
\end{tabular}

${ }^{a}$ Mouse- and human-based research summarised 
Asp1057 individuals are protected against CAD [24]. However, further confirmation is needed due to some limitations of the study [24].

Diminished insulin to IRS signalling has been implicated in the poor prognosis of diabetic patients following a stroke [25]. Similar to the heart, insulin mediates a protective effect on cerebral blood vessels, and insulin resistance is implicated in increased stroke incidence in diabetes. Tight control of glucose reduces the risk of non-fatal stroke by $57 \%[8,26]$, via similar protective mechanisms to those discussed above. IRS proteins may play a role in the response of neurons to ischaemia, as in a mouse model of obesity-induced type 2 diabetes there was reduced IRS to PI3K to Akt signalling in the brain [27]. In a recent study of type 2 diabetes patients, Zhang et al found that polymorphisms in IRS1 were associated with higher platelet activity and suboptimal responses to drugs such as clopidogrel (Plavix), which is used to prevent platelet adhesion in patients at risk of stroke [28]. A summary of IRS signalling in the brain is provided later in this review.

\section{IRS proteins and diabetic nephropathy}

Diabetic nephropathy is the leading cause of end-stage renal disease (ESRD) worldwide. Up to $40 \%$ of individuals with type 1 or type 2 diabetes will have clinically evident kidney disease during their lifetime [29]. The annual cost of chronic kidney disease to the National Health Service in England is estimated to be $£ 1.45$ billion [30]. Current treatment of diabetic nephropathy relies on tight glycaemic control, together with improved control of systemic and intraglomerular hypertension, using ACE inhibitors or angiotensin II receptor blockers as the mainstays of therapy [29]. Insulin signalling plays a critical role in kidney cell physiology and in the maintenance of the glomerular basement membrane (GBM). Defects in insulin signalling have been implicated in diabetic nephropathy at the level of the IR and IRS proteins (Table 2). The glomerular podocyte, the interdigitated foot processes of which form part of the GBM, responds to insulin by increasing glucose uptake via GLUT1 and GLUT4 transporters [31]. Nephrin is needed for this response, as it facilitates translocation of GLUT proteins to the plasma membrane via synaptobrevin (VAMP-2) binding [32]. The significance of these data for glomerular function in vivo was highlighted by the generation of podocyte-specific Insrknockout (PodIRKO) mice [33]. At 8 weeks of age, PodIRKO mice developed podocyte foot effacement, apoptosis and albuminuria, accompanied by increased type IV collagen staining and glomerulosclerosis [33]. The likely mechanism for this diabetic nephropathy-like phenotype in PodIRKO mice was reduced VEGF-A production, which is stimulated by insulin in podocytes in vitro and in vivo [34]. These data tally with previous reports detailing defective filtration barrier development and diabetic nephropathy-like symptoms in mice lacking
VEGF-A in podocytes [35]. Given the critical role of insulin signalling pathways in podocyte and GBM function, it is perhaps not surprising that numerous reports have also identified roles for IRS proteins in a range of kidney cells from mouse models. For example, IRS2 expression is enriched in glomerular podocytes, and podocytes from $\operatorname{Irs} 2^{-/-}$mice are significantly insulin resistant, suggesting a dominance of IRS2 over IRS1 in these cells [36]. IRS2 is also overexpressed in kidney tubular epithelial cells in biopsies from humans with diabetic nephropathy [37]. More data supporting a role for IRS protein in diabetic kidney are summarised in Table 2.

Epidemiology data on IRS proteins in diabetic nephropathy Decreasing GFR is widely accepted as a hallmark of diabetic nephropathy, where an inverse relationship exists between GFR and the progressive stages of diabetic nephropathy [38]. A region on chromosome 2q35-37 was highlighted in a cohort of Mexican-American diabetes patients as an area with the strongest GFR linkage [39]. Within this region, IRS1 was identified as a potential candidate gene [39]. Of note, this IRSI mutation is also associated with increased risk of CAD (see above). IRS1 SNPs were identified and analysed in MexicanAmerican individuals, to identify links between declining GFR and type 2 diabetes [39]. A specific missense mutation in IRSI occurring at codon 972 (Gly[972]Arg) was found to be the only SNP out of 18 that conferred association with GFR and serum triacylglycerol levels [39]. This SNP was responsible for $26 \%$ of the GFR-chromosome $2 q$ linkage, with carriers of this mutation presenting with significantly lower GFR [39]. Consistently, human mesangial cells transfected with mutant Gly(972)Arg IRS1 displayed lower insulin-induced phosphorylation of IRS1 and Akt [39]. These data suggest that even a single mutated codon in IRSI can negatively influence insulin signalling and an individual's GFR and renal function.

Chromosome 13q33.3 has also been implicated as a diabetic nephropathy susceptibility locus in patients with type 1 or type 2 diabetes [40]. This particular locus is situated at an intergenic region close to both $M Y O 16$ (encoding myosin heavy chain Myr 8) and IRS2 [40], which is located in region $13 q 34$ [41]. Following a genome-wide association scan of the Genetics of Kidneys in Diabetes (GoKinD) collections, $13 q 33.3$ was one of four loci associated with diabetic nephropathy in patients with type 1 diabetes [40]. In a Japanese subset of patients with type 2 diabetes, SNPs in these same loci increased diabetic nephropathy risk [40]. In the Joslin Study of Genetics of Nephrology in Type 2 Diabetes collection, multiple SNPs on chromosome 13q33.3 were identified with one particular SNP (rs1411766) exclusively associated with risk of early diabetic nephropathy and a trend towards an association with diabetic nephropathy in type 2 diabetes [40]. These data suggest that inherited changes in or around the IRS 2 gene may contribute to the genetic 
Table 2 Summary of data describing roles for IRS proteins in kidney function and diabetic nephropathy

\begin{tabular}{|c|c|c|c|c|}
\hline $\begin{array}{l}\text { IRS protein } \\
\text { involved }\end{array}$ & Rodent genotype/phenotype & $\begin{array}{l}\text { Kidney region/cell } \\
\text { affected }\end{array}$ & Main findings & Reference \\
\hline IRS1 & $\begin{array}{l}\text { OLETF rats that developed } \\
\text { diabetes and overt } \\
\text { nephropathy }\end{array}$ & Renal cortex & $\begin{array}{l}\text { IRS1 protein expression significantly reduced } \\
\text { vs control LETO rats }\end{array}$ & $\begin{array}{l}\text { Nakamura et al } \\
\text { (2015) [79] }\end{array}$ \\
\hline IRS1 & ROP mice & $\begin{array}{l}\text { Isolated mesangial } \\
\text { cells }\end{array}$ & $\begin{array}{l}\text { High glucose increased total IRS1 protein } \\
\text { expression and IRS1 phosphorylation in } \\
\text { mesangial cells from glomerulosclerosis-prone } \\
\text { ROP mice, and levels of IGF-1 receptor and } \\
\text { IGF-1 also increased. This is consistent with } \\
\text { previous data implicating IRS1 as the main IRS } \\
\text { protein involved in IGF-1 signalling. ROP } \\
\text { mesangial cells expressed less IGFBP-2 vs } \\
\text { control mice, and individuals with DN presented } \\
\text { with reduced IGFBP-2 in glomeruli vs control } \\
\text { individuals, indicating the potential for } \\
\text { IGFBP-2 as a marker identifying patient } \\
\text { susceptibility to DN. Low levels of IGFBP-2 } \\
\text { may play a partial role in increased IGF-1 } \\
\text { signalling via IRS1, as treatment of ROP } \\
\text { mesangial cells with exogenous IGFBP-2 } \\
\text { reduced glucose-induced increases in IRS1 } \\
\text { phosphorylation, protecting cells from } \\
\text { further damage }\end{array}$ & $\begin{array}{l}\text { Fornoni et al } \\
\qquad(2006)[80]^{\mathrm{a}} ; \\
\text { Myers et al } \\
\text { (1993) [81] }\end{array}$ \\
\hline IRS1 & NOD mice & $\begin{array}{l}\text { Isolated mesangial } \\
\text { cells }\end{array}$ & $\begin{array}{l}\text { Mesangial cells from NOD mice (model of type } 1 \\
\text { diabetes) with nephropathy displayed phenotypic } \\
\text { changes such as IGF-1 signalling pathway } \\
\text { activation }\end{array}$ & $\begin{array}{l}\text { Fornoni et al } \\
\quad(2006)[80]\end{array}$ \\
\hline IRS1 & $d b / d b$ mice & $\begin{array}{l}\text { Isolated mesangial } \\
\text { cells }\end{array}$ & $\begin{array}{l}\text { Mesangial cells from } d b / d b \text { mice (model of type } 2 \\
\text { diabetes) also displayed phenotypic changes, such } \\
\text { as IGF-1 signalling pathway activation }\end{array}$ & $\begin{array}{l}\text { Fornoni et al } \\
\quad(2006)[80]\end{array}$ \\
\hline IRS1 & C57BL/6 mice & $\begin{array}{l}\text { Isolated mesangial } \\
\text { cells }\end{array}$ & $\begin{array}{l}\text { High glucose treatment of control mesangial cells from } \\
\text { glomerulosclerosis-resistant C57BL/6 mice yielded } \\
\text { changes that were similar to those observed with } \\
\text { mesangial cells from NOD and } d b / d b \text { mice. These } \\
\text { data suggest that both type } 1 \text { and type } 2 \text { diabetes } \\
\text { stimulate the IGF-1 pathway }\end{array}$ & $\begin{array}{l}\text { Fornoni et al } \\
\quad(2006) \text { [80] }\end{array}$ \\
\hline IRS2 & $\begin{array}{l}\text { Wild-type, } \operatorname{Irs} 1^{-/-} \\
\text {and Irs } 2^{-/-} \text {mice }\end{array}$ & $\begin{array}{l}\text { Proximal tubule } \\
\text { epithelial cells }\end{array}$ & $\begin{array}{l}\text { Insulin-induced increases in tubular bicarbonate ion } \\
\text { absorption and Akt phosphorylation were seen in } \\
\text { wild-type mice, and this effect was decreased in } \\
\text { Irs } 2^{-/-} \text {mice. No defects in bicarbonate absorption } \\
\text { were seen in Irs } 1^{-/-} \text {mice, suggesting that IRS2 } \\
\text { coordinates the effects of insulin upon tubular } \\
\text { epithelial cell bicarbonate transport }\end{array}$ & $\begin{array}{l}\text { Zheng et al } \\
\quad(2005) \text { [82] }\end{array}$ \\
\hline IRS2 & Wild-type mice & $\begin{array}{l}\text { Tubular epithelial } \\
\text { cells }\end{array}$ & $\begin{array}{l}\text { IRS2 expression detected in embryonic kidney } \\
\text { tubules, adult proximal and distal tubules and } \\
\text { cortical collecting duct. BMP-7 increased IRS2 } \\
\text { signalling in HK-2 proximal tubule epithelial cells }\end{array}$ & $\begin{array}{l}\text { Hookham et } \\
\text { al (2013) [37] }\end{array}$ \\
\hline IRS2 & $\operatorname{Irs} 2^{-/-}$mice & Podocytes & $\begin{array}{l}\text { Irs } 2^{-/-} \text {podocytes were found to be insulin resistant } \\
\text { with respect to Akt signalling and GLUT4-mediated } \\
\text { glucose uptake in response to insulin }\end{array}$ & $\begin{array}{l}\text { Santamaria et } \\
\quad \text { al (2015) [36] }\end{array}$ \\
\hline
\end{tabular}

\footnotetext{
${ }^{\mathrm{a}}$ Mouse- and human-based research summarised
}

DN, Diabetic nephropathy; IGFBP-2, IGF binding protein-2; LETO, Long-Evans Tokushima Otsuka (rats); OLETF, Otsuka Long-Evans Tokushima fatty (rats); ROP, ragged olygosyndactilism pintail (mice)

predisposition or increased risk of developing diabetic nephropathy in some diabetic patients.

IRS proteins in diabetic nephropathy: a novel therapeutic target? Given the changes in IRS proteins in the diabetic kidney, the question arises: can we alter IRS protein levels to provide benefit and reduce the severity of diabetic nephropathy in patients? A second question arises: would increasing or decreasing IRS protein levels (and therefore insulin signalling) be of benefit in the diabetic kidney? Data from the Coward group 
showed that insulin-mediated VEGF production is critical for podocyte survival in the kidney, suggesting that increasing IRS protein levels may help to rescue insulin signalling in the diabetic kidney [33]. However, treatment of $d b / d b$ mice with bioactive peptides nephrilin or anephril significantly reduced IRS2, p-IRS1-Ser307, serum/glucocorticoid-regulated kinase 1 and phospho-PKC- $\alpha / \beta$ which, when elevated, are associated with diabetic nephropathy [42]. A concomitant decrease in albuminuria was also detected in these mice, suggesting a beneficial effect of these peptides on renal function [41]. Streptozotocin (STZ)-treated mice yielded higher nuclear expression of IRS2, Rictor and phospho-PKC in fractionated renal tissue extracts, which was reduced by nephrilin in vivo [42]. These data suggest that, as a component of mTORC2, a nuclear complex of IRS2 and Rictor exists that is disrupted by nephrilin, potentially implicating this complex in albuminuria in diabetic nephropathy [42]. In contrast, data from Wei et al suggest that modulation of hypoxia-mediated regulation of IRS2 in the liver can sensitise hepatic insulin signalling [43]. VEGF inhibition improved glucose tolerance in $d b / d b$ mice and this augmented insulin signalling via IRS2 induction. Hepatic hypoxia was induced, which subsequently activated hepatic hypoxia-inducible factor- $2 \alpha$ (HIF- $2 \alpha$ ) and improved insulin signalling as HIF- $2 \alpha$ promotes IRS2 expression [43]. Complementary work from Taniguchi et al showed that specific hepatic deletion of the gene encoding prolyl hydroxylase 3 ( $P h d 3$, also known as $E g \ln 1$ ) in mice modified insulin sensitivity by eliciting HIF- $2 \alpha$ stabilisation, resulting in greater IRS2 transcription and downstream Akt signalling [44]. The relationship between HIF- $2 \alpha$ and IRS 2 therefore provides a new therapeutic approach to increase IRS2 levels in the treatment of diabetes and related complications, should this be demonstrated to be therapeutically advantageous in patients [44]. We and others are currently exploring the effects of increasing IRS2 levels in the diabetic kidney using similar hypoxia-mediated strategies.

\section{IRS proteins in diabetic retinopathy}

Diabetic retinopathy is a common microvascular complication of diabetes characterised by damage to a number of retinal cell types including retinal pigment epithelia, Müller cells and retinal vascular cells [45]. A significant feature of diabetic retinopathy is the loss of retinal blood vessels, leading to retinal ischaemia/hypoxia and then to pathogenic neovascularisation and progressive vision loss [46]. IRS proteins are expressed in the normal retina, and both IRS1 and IRS2 have been implicated in normal retinal development and diabetic retinopathy. Some of these data are discussed below.

Retinal Müller cells: a primary site of IRS signalling in the retina IRS proteins are heavily phosphorylated on tyrosine, serine and threonine residues [37, 47, 48]. Aguirre et al originally showed that c-Jun N-terminal kinase (JNK)-induced IRS1 ${ }^{\text {Ser307 }}$ phosphorylation prevents IR-IRS interactions, resulting in impaired insulin signalling [49, 50]. In contrast, Copps et al showed that substitution of Ser307 with Ala resulted in severe insulin resistance and impaired insulin signalling, thus positively implicating Ser307 in maintaining insulin signalling and sensitivity [27]. With regard to the retina, the Steinle group showed in both rat retinal Müller cells and human retinal endothelial cells grown in high glucose, that TNF- $\alpha$ increased IRS1 ${ }^{\mathrm{Ser} 307}$ phosphorylation, insulin resistance and retinal cell death [51-53]. This effect was reversed by the $\beta$ adrenergic agonist salmeterol, suggesting that $\beta$-adrenergic receptor agonists can restore insulin signalling and protect retinal Müller cells from apoptosis in diabetes [53]. Similar effects were seen in retinal endothelial cells, where hyperglycaemia caused elevated TNF- $\alpha$, increased IRS $1^{\text {Ser307 }}$ phosphorylation and loss of IRS1 protein, likely via suppressor of cytokine signalling 3 (SOCS3)-mediated targeting to the proteasome [54]. Given the critical role of retinal capillary loss during diabetic retinopathy pathogenesis, these data provide evidence that rescuing insulin signalling may decrease retinal endothelial cell apoptosis, thus potentially improving diabetic retinopathy outcomes. Supporting this hypothesis, two reports indicated that pioglitazone, a peroxisome proliferator-activated receptor- $\gamma$ (PPAR $\gamma$ ) agonist reduced TNF- $\alpha$-mediated IRS1 ${ }^{\text {Ser307 }}$ phosphorylation and insulin resistance in diabetic rat retinas, with a concomitant improvement in retinal function [55]. Pioglitazone was shown to decrease Müller cell and retinal endothelial cell apoptosis, likely via increased insulinmediated pro-survival signalling [55]. Similar data were obtained using sodium salicylate [56], which was shown to reverse insulin resistance via inhibition of TNF- $\alpha$-mediated $\operatorname{Ikk} \beta$ driven inflammatory responses $[57,58]$.

Mouse models have also demonstrated key roles for IRS proteins in retinal development as well as disease. A summary of these data is shown in Table 3.

\section{IRS proteins in the brain}

The main diabetic complication affecting the brain is the increased risk of stroke (discussed above). However, defective insulin signalling has also been identified in the central nervous system in diabetes, and has been linked to altered nutrient homeostasis, an increased risk of Alzheimer's disease and changes in lifespan. The role of insulin signalling in the brain has been reviewed expertly elsewhere [59]. The main effects of insulin in the brain appear to be on energy homeostasis, neuronal proliferation, Tau phosphorylation and reproductive endocrinology [59]. Centrally administered insulin can improve peripheral insulin sensitivity in the liver by reducing hepatic glucose production [60]. Mice lacking the IR in 
Table 3 Summary of data linking IRS proteins to diabetic retinopathy

\begin{tabular}{|c|c|c|c|c|}
\hline $\begin{array}{l}\text { IRS } \\
\text { involved }\end{array}$ & $\begin{array}{l}\text { Rodent genotype/ } \\
\text { phenotype }\end{array}$ & $\begin{array}{l}\text { Organ } \\
\text { affected }\end{array}$ & Main findings & Reference \\
\hline IRS2 & $\operatorname{Irs} 2^{-/-}$mice & Eye (retina) & $\begin{array}{l}\text { Irs } 2 \text { gene deletion triggered photoreceptor apoptosis with a } 50 \% \\
\text { reduction in cells by day } 14 \text {, with almost complete photoreceptor } \\
\text { loss by } 16 \text { months of age. In contrast, normal retinal } \\
\text { morphology was maintained in } \operatorname{Irs} 1^{-/-} \text {mice at up to } 2 \text { years of } \\
\text { age. Retinas from } \operatorname{Irs} 2^{-/-} \text {mice displayed higher caspase-3 } \\
\text { cleavage and activation, and lower Akt phosphorylation, } \\
\text { consistent with apoptotic cell death. Expression of rhodopsin } \\
\text { (the light-sensing G-protein-coupled receptor in the retina) was } \\
\text { reduced in Irs } 2^{-/-} \text {retinas and retinal electrical function showed } \\
\text { that } I r s 2^{-/-} \text {mice had reduced dark- and light-adapted responses, } \\
\text { suggesting lower rod and cone activity, respectively }\end{array}$ & Yi et al (2005) [45] \\
\hline IRS2 & $\begin{array}{l}\text { 9- and 12-week-old } \\
I r s 2^{-/-} \text {mice }\end{array}$ & Eye (retina) & $\begin{array}{l}\text { At } 9 \text { weeks, activation of Müller glial cells was apparent, as } \\
\text { demonstrated by outer retinal layers that were considerably } \\
\text { thinner than their wild-type counterparts. Thinning extended to } \\
\text { each retinal layer in } 12 \text {-week-old Irs } 2^{--} \text {mice. Changes in } \\
\text { microglia were also detected at } 9 \text { weeks with } \\
\text { swelling/retraction of microglial processes observed. In both } \\
\text { age groups, shortened rod segments were apparent, and } \\
\text { rhodopsin distribution in the rod photoreceptors of the outer } \\
\text { nuclear layer was abnormal. Photoreceptor atrophy, as well as } \\
\text { synaptic changes at the outer plexiform layer were also } \\
\text { observed. Retinal ganglion cell degeneration was present in } \\
12 \text {-week-old Irs } 2^{-/-} \text {mice with the progressive loss of these } \\
\text { cells observed }\end{array}$ & $\begin{array}{l}\text { Albert-Fort et al (2014) } \\
\text { [83]; Kern and } \\
\text { Barber (2008) [84] }\end{array}$ \\
\hline IRS1, IRS2 & $\begin{array}{l}\text { STZ-induced } \\
\text { model of type } 1 \text { diabetes } \\
\text { in Sprague-Dawley } \\
\text { rats }\end{array}$ & Eye (retina) & $\begin{array}{l}\text { At } 1 \text { month post STZ-induced diabetes, retinal IRS1/2-associated } \\
\text { PI3K activity, Akt1 and Akt3 kinase activity, and } \\
\text { p70S6K/pGSK3 } \beta \text { were decreased with no change in retinal } \\
\text { IRS1/2 expression or tyrosine phosphorylation. Such rapid } \\
\text { signalling changes and alterations in p70S6K and GSK3 } \beta \text { as a } \\
\text { result of hyperglycaemia provide further evidence of a role for } \\
\text { insulin signalling in retinal cell survival. After } 3 \text { months, IR- } \beta \\
\text { expression, autophosphorylation and kinase activity was } \\
\text { decreased in diabetic retina. Moreover, IRS2 protein expression } \\
\text { was decreased whereas IRS1 was unchanged. These data } \\
\text { suggest that IR signalling is compromised relatively early in the } \\
\text { diabetic retina, and suggests a critical role for reduced insulin } \\
\text { in IRS2 signalling in progressive retinal degeneration }\end{array}$ & Reiter et al (2006) [85] \\
\hline
\end{tabular}

P706K, phospho-p70 S6 kinase

neurons (NIRKO mice) developed diet-sensitive obesity, with increased body fat and plasma leptin levels [61]. Female mice lacking IRS2 are infertile, due to reduced levels of luteinising hormone, prolactin and sex steroids, linking insulin signalling to hypothalamic control of reproductive endocrinology [62]. IRS2 expression in the hypothalamus is also important in energy homeostasis, as mice lacking IRS2 in a specific subset of hypothalamic neurons display hyperphagia, obesity and increased body length [63]. Whole-body $\operatorname{Irs} 2^{-1-}$ mice have brains that are $30 \%$ smaller than wild-types, due to a defect in neuronal proliferation during development [64]. Elevated Tau phosphorylation was also detected in $\operatorname{Irs} 2^{-1-}$ mouse brains, suggesting a potential link between IRS2 and Alzheimer's disease [64]. Consistently, levels of IRS2 (and IRS1) were reduced in the neurons of the temporal cortex of post-mortem human brains from Alzheimer's patients compared with controls [65]. Others have demonstrated post-mortem insulin resistance in the brains of Alzheimer's patients, specifically in the hippocampus, providing a link to cognitive defects and decreased memory formation [66]. Mice lacking IRS2 demonstrated deficiencies in $\mathrm{N}$-methyl-D-aspartate receptor-mediated long-term potentiation and hippocampal plasticity $[67,68]$. Increased serine phosphorylation of IRS proteins, a feature of insulin resistance, was also detected in the brains of Alzheimer's patients [66]. Co-localisation of pSer-IRS1 and amyloid- $\beta$ was demonstrated in these brains, and amyloid- $\beta$ oligomers injected directly into the brain stimulated IRS1 protein phosphorylation and JNK activation [69]. Importantly, exendin-4, a glucose-lowering drug that activates glucagon-like peptide-1 (GLP-1) signalling, was shown to prevent this amyloid- $\beta$-induced insulin resistance and increase spatial memory in non-diabetic mice [69]. Together, 
these data support the notion that changes in insulin signalling during Alzheimer's disease may represent an insulin-resistant state in the brain, and that targeting these changes may improve outcomes for Alzheimer's patients [66].

\section{IRS proteins in diabetic neuropathy}

Diabetic neuropathy is a common complication of diabetes, affecting $50 \%$ of patients. Many patients suffer from nerve pain, reduced proprioception (the body's ability to sense joint movement and position) and peripheral insensitivity, leading to foot ulcers that may in severe cases require amputation [70]. Many different pathways have been implicated in the pathogenesis of diabetic neuropathy, including decreased neurotrophic growth factors such as IGF-1 [71], advanced glycation end-products and oxidative stress [72]. Impaired insulin signalling has been implicated in the pathogenesis of diabetic neuropathy. Insulin is a neurotrophic factor for the dorsal root ganglion, and IRS proteins are expressed in these cells, with IRS2 expression being most abundant in both myelinated and unmyelinated

Table 4 Summary of animal model data implicating IRS proteins in diabetic neuropathy

\begin{tabular}{llll}
\hline IRS involved & $\begin{array}{l}\text { Rodent genotype/ } \\
\text { phenotype }\end{array}$ & Organ affected & Main finding(s)
\end{tabular}

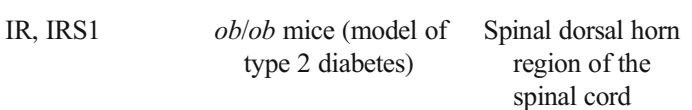

IR- $\beta$, IRS1, IRS2 ZDF rats, a long-term model of PDN
Sensory neurons and dorsal root ganglion
Diabetic $o b / o b$ mice displayed PDN in the form of mechanical hyperalgesia, as demonstrated by low paw-withdrawal thresholds. This decrease in withdrawal threshold coincided with reduced p-IRS1 and IR-positive spinal dorsal horn neurons in these mice. As PDN progresses, IR and p-IRS1 levels decline. Also, with progression of PDN, pJAK2 and p-STAT3 levels increase, with specific activation of JAK2/STAT3 occurring in this area. Administration of a JAK2/STAT3 pathway inhibitor reverts the pain threshold to normal levels in $o b / o b$ mice. The JAK/STAT inhibitor also prevented the decrease in IR and p-IRS1, suggesting a link between JAK/STAT, IR/IRS1 signalling and PDN

Oral administration of vildagliptin reduced neuronal atrophy and improved neuropathy as evaluated by motor and sensory nerve conduction velocity. Vildagliptin preserved intra-epidermal nerve fibre density in GK rats, which indicates beneficial neuropathic effects. Vildagliptin increased GLP-1 signals such as CREB; PKB/Akt phosphorylation in the dorsal root ganglion, with changes in IRS2 ${ }^{\text {Tyr }} / \mathrm{IRS}^{\mathrm{Ser}}$ phosphorylation also seen. Crosstalk exists between insulin and GLP-1 at least in part through CREB phosphorylation, which promotes IRS2 expression. Of note, hyperglycaemia in these diabetic GK rats was unchanged following vildagliptin treatment, suggesting that vildagliptin functions to inhibit neuropathy development independently of hyperglycaemia

Progressive slowing of nerve conduction in the ZDF rats is detected. ZDF rats are more sensitive to mechanical withdrawal (similar to $o b / o b$ mice), suggesting pain sensation from a non-painful stimulation of the skin. Dorsal root ganglion mRNA levels of IR- $\beta$, IRS1 and IRS2, Akt, PI3K and GLUT4 were preserved or slightly increased in ZDF rats

IRS2

$o b / o b$ mice (model of Dorsal root ganglion
type 2 diabetes), and
STZ C57BL/6 mice
(model of type
1 diabetes)
ganglion neurons. IRS2 Ser phosphorylation increases in
Total IRS2 levels decreased in diabetic $o b / o b$ dorsal root dorsal root ganglion neurons from diabetic $o b / o b$ mice and dorsal root ganglion neurons from an STZ mouse model. Suboptimal dorsal root ganglion insulin signalling may be caused by increased IRS serine phosphorylation, leading to IRS degradation, decreasing IR/IRS interaction. In healthy neurons, insulin increases neurite outgrowth. Neurons from $o b / o b$ mice were unable to efficiently respond to insulin. Increased IRS2 serine phosphorylation and subsequent insulin resistance may modulate neuronal insulin signalling to promote peripheral nerve dysfunction leading to PDN.
Kou et al (2013) [73]

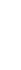

$[77$

boi et al (2015)

Brussee et al (2008) [86]

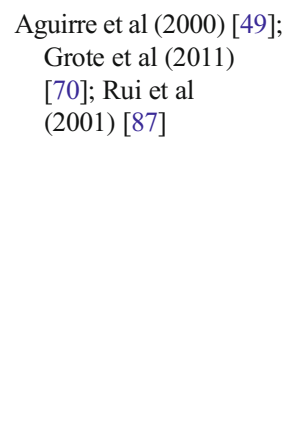

CREB, cAMP response element binding protein; GK, Goto-Kakizaki (rats); PDN, painful diabetic neuropathy; ZDF, Zucker diabetic fatty (rats) 
neurons [70]. In animal models of diabetes, several reports have identified a reduction in insulin sensitivity of dorsal root ganglion cells (summarised in Table 4). Reduced IRS2 expression was linked to hyperalgesia in diabetic mice, which was reversed by inhibition of the JAK2/signal transducer and activator of transcription 3 (STAT3) pathway [73]. Importantly, incretin drugs that are widely used to treat type 2 diabetes have been shown to reduce the severity of diabetic neuropathy in pre-clinical models. Exendin-4, vildagliptin and alogliptin all improved nerve conductance velocity in diabetic rats and reversed nerve damage [74-76]. These effects were linked to an improvement in both GLP-1 and insulin signalling, with expression of IRS2 being increased in neurons from diabetic animals treated with vildagliptin [77]. Thus, the preservation or restoration of neuronal insulin signal transduction pathways and IRS2 expression would seem to be a useful avenue for exploring new and improved therapeutic interventions in diabetic neuropathy.

\section{Concluding remarks}

A summary of the role of IRS proteins in organs affected by diabetic complications is shown in Fig. 1. It is clear from the literature that reduced insulin signalling is implicated not just in the aetiology of diabetes but also in the pathogenesis of diabetic complications. Given their central role in insulin signalling, it is perhaps not surprising that abundant evidence exists to show that IRS proteins are implicated in vascular complications of diabetes. A slew of mouse data and genetic studies in human patients strengthen the argument that changes in IRS function contribute to diabetic complications in affected organs such as the heart, kidney, eye and nervous system. The vascular aetiology of many diabetic complications makes it reasonable to assume that changes in IRS protein expression or phosphorylation occur as a result of chronic hyperglycaemia, which triggers vascular damage. Data from mice showing that increasing IRS2 levels provides relief in terms of hepatic insulin resistance are very encouraging.

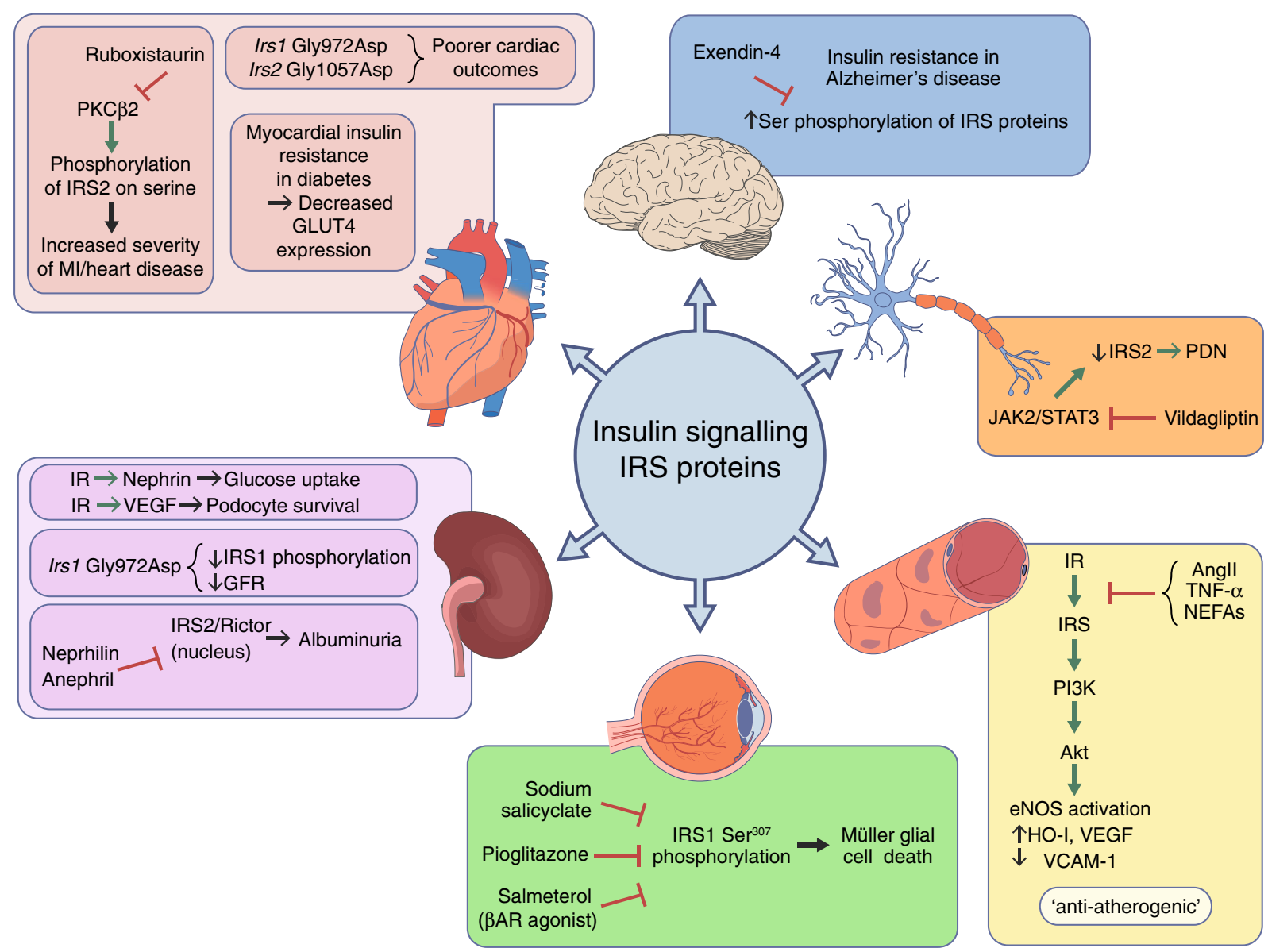

Fig. 1 IRS proteins in organs affected by diabetic complications. A selection of data from animal and human studies supporting changes in IRS proteins during diabetic heart disease (pink panel), diabetic nephropathy (purple panel), diabetic retinopathy (green panel), diabetic vascular disease (yellow panel), diabetic neuropathy (orange panel) and Alzheimer's disease (blue panel). Details and supporting references are provided in the text. Red T-bar represents inhibition; green arrow represents activation; black arrow represents 'leading to'. AngII, angiotensin II; $\beta$ AR, $\beta$-adrenergic receptor; PDN, painful diabetic neuropathy 
Emerging gene-editing technologies, such as CRISPR (clustered regularly interspaced short palindromic repeats)/Cas9 and TALENS (transcription activator-like effector nucleases), will allow deletion or insertion of IRS1, IRS2 or both proteins in vascular cells damaged in diabetes. These future experiments will shed new light on the role of IRS proteins in diabetic vascular complications, and also expand our ability to provide novel therapeutic strategies aimed at boosting IRS protein levels and improving the outcomes for patients with diabetic complications.

Acknowledgements The authors apologise to those colleagues whose work could not be included due to space limitations. We thank colleagues in the Centre for Experimental Medicine, Queen's University Belfast for advice and support.

Funding Work in the laboratory of DPB is supported by the Wellcome Trust, the Northern Ireland Kidney Research Fund and the Northern Ireland Department of Education and Learning (DEL).

Duality of interest The authors declare that there is no duality of interest associated with this manuscript.

Contribution statement DPB and DPL were responsible for manuscript conception and drafting. MFW provided revisions and suggestions and all three authors approved the final version of the manuscript.

Open Access This article is distributed under the terms of the Creative Commons Attribution 4.0 International License (http:// creativecommons.org/licenses/by/4.0/), which permits unrestricted use, distribution, and reproduction in any medium, provided you give appropriate credit to the original author(s) and the source, provide a link to the Creative Commons license, and indicate if changes were made.

\section{References}

1. Sadagurski M, Dong XC, Myers MG Jr, White MF (2014) Irs2 and Irs4 synergize in non-LepRb neurons to control energy balance and glucose homeostasis. Mol Metab 3:55-63

2. White MF (2016) Insulin action. In: Holt RIG, Cockram CS, Flyvbjerg A, Goldstein BJ (eds) Textbook of diabetes. Wiley, Chichester

3. Withers DJ, Gutierrez JS, Towery H et al (1998) Disruption of IRS2 causes type 2 diabetes in mice. Nature 391:900-904

4. Araki E, Lipes MA, Patti ME et al (1994) Alternative pathway of insulin signalling in mice with targeted disruption of the IRS-1 gene. Nature 372:186-190

5. Withers DJ, Burks DJ, Towery HH, Altamuro SL, Flint CL, White MF (1999) Irs-2 coordinates Igf-1 receptor-mediated [beta]-cell development and peripheral insulin signalling. Nat Genet 23:32-40

6. DiabetesUK (2015) Diabetes: facts and stats. Available from https://www.diabetes.org.uk/Documents/Position\%20 statements/Facts\%20and\%20stats\%20June\%202015.pdf, accessed 7 June 2016
7. I.D.F. (2014) IDF diabetes atlas. Available from https://www.idf. org/sites/default/files/Atlas-poster-2014_EN.pdf, accessed 3 November 2015

8. Nathan DM, Cleary PA, Backlund JY et al (2005) Intensive diabetes treatment and cardiovascular disease in patients with type 1 diabetes. N Engl J Med 353:2643-2653

9. King GL, Park K, Li Q (2016) Selective insulin resistance and the development of cardiovascular diseases in diabetes: the 2015 Edwin Bierman award lecture. Diabetes 65:1462-1471

10. Park K, Li Q, Rask-Madsen C et al (2013) Serine phosphorylation sites on IRS2 activated by angiotensin II and protein kinase $\mathrm{C}$ to induce selective insulin resistance in endothelial cells. Mol Cell Biol 33:3227-3241

11. Connelly KA, Kelly DJ, Zhang Y et al (2009) Inhibition of protein kinase C-beta by ruboxistaurin preserves cardiac function and reduces extracellular matrix production in diabetic cardiomyopathy. Circ Heart Fail 2:129-137

12. Liu Y, Lei S, Gao X et al (2012) PKCbeta inhibition with ruboxistaurin reduces oxidative stress and attenuates left ventricular hypertrophy and dysfunction in rats with streptozotocin-induced diabetes. Clin Sci 122:161-173

13. Liu Y, Jin J, Qiao S et al (2015) Inhibition of PKCbeta2 overexpression ameliorates myocardial ischaemia/reperfusion injury in diabetic rats via restoring caveolin-3/Akt signaling. Clin Sci 129: 331-344

14. Ladage D, Tilemann L, Ishikawa K et al (2011) Inhibition of $\mathrm{PKCalpha/beta} \mathrm{with} \mathrm{ruboxistaurin} \mathrm{antagonizes} \mathrm{heart} \mathrm{failure} \mathrm{in} \mathrm{pigs}$ after myocardial infarction injury. Circ Res 109:1396-1400

15. Laustsen PG, Russell SJ, Cui L et al (2007) Essential role of insulin and insulin-like growth factor 1 receptor signaling in cardiac development and function. Mol Cell Biol 27:1649-1664

16. Rask-Madsen C, Li Q, Freund B et al (2010) Loss of insulin signaling in vascular endothelial cells accelerates atherosclerosis in apolipoprotein E null mice. Cell Metab 11:379-389

17. Cook SA, Varela-Carver A, Mongillo M et al (2010) Abnormal myocardial insulin signalling in type 2 diabetes and leftventricular dysfunction. Eur Heart J 31:100-111

18. Baroni MG, D’Andrea MP, Montali A et al (1999) A common mutation of the insulin receptor substrate- 1 gene is a risk factor for coronary artery disease. Arterioscler Thromb Vasc Biol 19: 2975-2980

19. Hitman GA, Hawrami K, McCarthy MI et al (1995) Insulin receptor substrate-1 gene mutations in NIDDM; implications for the study of polygenic disease. Diabetologia 38:481-486

20. Jellema A, Zeegers MP, Feskens EJ, Dagnelie PC, Mensink RP (2003) Gly972Arg variant in the insulin receptor substrate-1 gene and association with Type 2 diabetes: a meta-analysis of 27 studies. Diabetologia 46:990-995

21. Liu W, Zhou X, Yu F, Hu J, Hu W (2013) Arg972 Insulin receptor substrate-1 is associated with decreased serum angiotensinconverting enzyme 2 levels in acute myocardial infarction patients: in vivo and in vitro evidence. Cardiovasc Diabetol 12:151

22. Vats S, Matharoo KK, Singh AP, Bhanwer AJS, Sambyal V (2013) Polymorphisms in PPAR $\gamma$ (Pro12Ala, C1431T), IRS1 (G972R), IRS2 (G1057D) and Coronary artery disease. Int J Diabetes Dev Ctries 33:192-201

23. Strohmer B, Reiter R, Holzl B, Paulweber B (2004) Lack of association of the Gly972Arg mutation of the insulin receptor substrate1 gene with coronary artery disease in the Austrian population. J Intern Med 255:146-147

24. Chan SH, Chen JH, Li YH, Tsai LM (2012) Gly1057Asp polymorphism of insulin receptor substrate- 2 is associated with coronary artery disease in the Taiwanese population. J Biomed Sci 19:100

25. Kim B, Sullivan KA, Backus C, Feldman EL (2011) Cortical neurons develop insulin resistance and blunted Akt signaling: a 
potential mechanism contributing to enhanced ischemic injury in diabetes. Antioxid Redox Signal 14:1829-1839

26. NDIC (2008) DCCT and EDIC: the diabetes control and complications trial and follow-up study. Available from www.niddk.nih. gov/about-niddk/research-areas/diabetes/dcct-edic-diabetescontrol-complications-trial-follow-up-study/Documents/DCCTEDIC_508.pdf, accessed 7 June 2016

27. Copps KD, Hancer NJ, Opare-Ado L, Qiu W, Walsh C, White MF (2010) Irs1 serine 307 promotes insulin sensitivity in mice. Cell Metab 11:84-92

28. Zhang D, Zhang X, Liu D et al (2016) Association between insulin receptor substrate-1 polymorphisms and high platelet reactivity with clopidogrel therapy in coronary artery disease patients with type 2 diabetes mellitus. Cardiovasc Diabetol 15:50

29. Parving H-H, Mauer M, Ritz E (2004) Diabetic nephropathy. In: Brenner and Rector's the kidney. Saunders, Philadelphia, USA 1411-1455

30. NHS (2013) NHS kidney care. Available from http://webarchive. nationalarchives.gov.uk/20130504185629/kidneycare.nhs.uk/\#, accessed 19 July 2016 (archived)

31. Coward RJ, Welsh GI, Yang J et al (2005) The human glomerular podocyte is a novel target for insulin action. Diabetes 54:30953102

32. Coward RJ, Welsh GI, Koziell A et al (2007) Nephrin is critical for the action of insulin on human glomerular podocytes. Diabetes 56: $1127-1135$

33. Welsh GI, Hale LJ, Eremina V et al (2010) Insulin signaling to the glomerular podocyte is critical for normal kidney function. Cell Metab 12:329-340

34. Hale LJ, Hurcombe J, Lay A et al (2013) Insulin directly stimulates VEGF-A production in the glomerular podocyte. Am J Physiol Ren Physiol 305:F182-F188

35. Eremina V, Sood M, Haigh J et al (2003) Glomerular-specific alterations of VEGF-A expression lead to distinct congenital and acquired renal diseases. J Clin Invest 111:707-716

36. Santamaria B, Marquez E, Lay A et al (2015) IRS2 and PTEN are key molecules in controlling insulin sensitivity in podocytes. Biochim Biophys Acta 1853:3224-3334

37. Hookham MB, O’Donovan HC, Church RH et al (2013) Insulin receptor substrate- 2 is expressed in kidney epithelium and upregulated in diabetic nephropathy. FEBS J 280:3232-3243

38. Eknoyan G, Levin NW (2002) K/DOQI clinical practice guidelines for chronic kidney disease: Evaluation, classification, and stratification. Am J Kidney Dis 39:S14-S266

39. Thameem F, Puppala S, Schneider J et al (2012) The Gly(972)Arg variant of human IRS1 gene is associated with variation in glomerular filtration rate likely through impaired insulin receptor signaling. Diabetes 61:2385-2393

40. Pezzolesi MG, Poznik GD, Skupien J et al (2011) An intergenic region on chromosome 13q33.3 is associated with the susceptibility to kidney disease in type 1 and 2 diabetes. Kidney Int 80:105-111

41. Bernal D, Almind K, Yenush L et al (1998) Insulin receptor substrate-2 amino acid polymorphisms are not associated with random type 2 diabetes among Caucasians. Diabetes 47:976-979

42. Singh BK, Singh A, Mascarenhas DD (2010) A nuclear complex of rictor and insulin receptor substrate-2 is associated with albuminuria in diabetic mice. Metab Syndr Relat Disord 8:355-363

43. Wei K, Piecewicz SM, McGinnis LM et al (2013) A liver Hif2[alpha]-Irs2 pathway sensitizes hepatic insulin signaling and is modulated by Vegf inhibition. Nat Med 19:1331-1337

44. Taniguchi CM, Finger EC, Krieg AJ et al (2013) Cross-talk between hypoxia and insulin signaling through $\mathrm{Phd} 3$ regulates hepatic glucose and lipid metabolism and ameliorates diabetes. Nat Med 19:1325-1330
45. Yi X, Schubert M, Peachey NS et al (2005) Insulin receptor substrate 2 is essential for maturation and survival of photoreceptor cells. J Neurosci 25:1240-1248

46. Stitt AW, Lois N, Medina RJ, Adamson P, Curtis TM (2013) Advances in our understanding of diabetic retinopathy. Clin Sci 125:1-17

47. Copps KD, White MF (2012) Regulation of insulin sensitivity by serine/threonine phosphorylation of insulin receptor substrate proteins IRS1 and IRS2. Diabetologia 55:2565-2582

48. Carew RM, Browne MB, Hickey FB, Brazil DP (2011) Insulin receptor substrate 2 and $\mathrm{FoxO} 3$ a signalling are involved in $\mathrm{E}$ cadherin expression and transforming growth factor- $\beta 1$-induced repression in kidney epithelial cells. FEBS J 278:3370-3380

49. Aguirre V, Uchida T, Yenush L, Davis R, White MF (2000) The cJun NH2-terminal kinase promotes insulin resistance during association with insulin receptor substrate-1 and phosphorylation of Ser307. J Biol Chem 275:9047-9054

50. Aguirre V, Werner ED, Giraud J, Lee YH, Shoelson SE, White MF (2002) Phosphorylation of Ser307 in insulin receptor substrate-1 blocks interactions with the insulin receptor and inhibits insulin action. J Biol Chem 277:1531-1537

51. Jiang Y, Zhang Q, Soderland C, Steinle JJ (2012) TNFalpha and SOCS3 regulate IRS-1 to increase retinal endothelial cell apoptosis. Cell Signal 24:1086-1092

52. Walker RJ, Anderson NM, Jiang Y, Bahouth S, Steinle JJ (2011) Role of beta-adrenergic receptor regulation of TNF-alpha and insulin signaling in retinal Muller cells. Invest Ophthalmol Vis Sci 52: 9527-9533

53. Walker RJ, Anderson NM, Bahouth S, Steinle JJ (2012) Silencing of insulin receptor substrate-1 increases cell death in retinal Muller cells. Mol Vis 18:271-279

54. Jiang Y, Biswas SK, Steinle JJ (2014) Serine 307 on insulin receptor substrate 1 is required for SOCS3 and TNF-alpha signaling in the rMC-1 cell line. Mol Vis 20:1463-1470

55. Jiang Y, Thakran S, Bheemreddy R et al (2014) Pioglitazone normalizes insulin signaling in the diabetic rat retina through reduction in tumor necrosis factor $\alpha$ and suppressor of cytokine signaling 3 . J Biol Chem 289:26395-26405

56. Jiang Y, Thakran S, Bheemreddy R, Coppess W, Walker RJ, Steinle JJ (2015) Sodium salicylate reduced insulin resistance in the retina of a type 2 diabetic rat model. PLoS One 10, e0125505

57. Kim JK, Kim YJ, Fillmore JJ et al (2001) Prevention of fat-induced insulin resistance by salicylate. J Clin Invest 108:437-446

58. Yuan M, Konstantopoulos N, Lee J et al (2001) Reversal of obesityand diet-induced insulin resistance with salicylates or targeted disruption of Ikkbeta. Science 293:1673-1677

59. Plum L, Schubert M, Bruning JC (2005) The role of insulin receptor signaling in the brain. Trends Endocrinol Metab 16:59-65

60. Obici S, Zhang BB, Karkanias G, Rossetti L (2002) Hypothalamic insulin signaling is required for inhibition of glucose production. Nat Med 8:1376-1382

61. Bruning JC, Gautam D, Burks DJ et al (2000) Role of brain insulin receptor in control of body weight and reproduction. Science 289: 2122-2125

62. Burks DJ, Font de Mora J, Schubert M et al (2000) IRS-2 pathways integrate female reproduction and energy homeostasis. Nature 407: 377-382

63. Choudhury AI, Heffron H, Smith MA et al (2005) The role of insulin receptor substrate 2 in hypothalamic and beta cell function. J Clin Invest 115:940-950

64. Schubert M, Brazil DP, Burks DJ et al (2003) Insulin receptor substrate-2 deficiency impairs brain growth and promotes tau phosphorylation. J Neurosci 23:7084-7092

65. Moloney AM, Griffin RJ, Timmons S, O'Connor R, Ravid R, O'Neill C (2010) Defects in IGF-1 receptor, insulin receptor and 
IRS-1/2 in Alzheimer's disease indicate possible resistance to IGF1 and insulin signalling. Neurobiol Aging 31:224-243

66. Talbot K, Wang HY, Kazi H et al (2012) Demonstrated brain insulin resistance in Alzheimer's disease patients is associated with IGF-1 resistance, IRS-1 dysregulation, and cognitive decline. J Clin Invest 122:1316-1338

67. Martin ED, Sanchez-Perez A, Trejo JL et al (2012) IRS-2 deficiency impairs NMDA receptor-dependent long-term potentiation. Cereb Cortex 22:1717-1727

68. Costello DA, Claret M, Al-Qassab H et al (2012) Brain deletion of insulin receptor substrate 2 disrupts hippocampal synaptic plasticity and metaplasticity. PLoS One 7, e31124

69. Bomfim TR, Forny-Germano L, Sathler LB et al (2012) An antidiabetes agent protects the mouse brain from defective insulin signaling caused by Alzheimer's disease- associated Abeta oligomers. J Clin Invest 122:1339-1353

70. Grote CW, Morris JK, Ryals JM, Geiger PC, Wright DE (2011) Insulin receptor substrate 2 expression and involvement in neuronal insulin resistance in diabetic neuropathy. Exp Diabetes Res 2011: 212571

71. Sullivan KA, Kim B, Feldman EL (2008) Insulin-like growth factors in the peripheral nervous system. Endocrinology 149:59635971

72. Zochodne DW (2007) Diabetes mellitus and the peripheral nervous system: manifestations and mechanisms. Muscle Nerve 36:144166

73. Kou ZZ, Li CY, Tang J et al (2013) Down-regulation of insulin signaling is involved in painful diabetic neuropathy in type 2 diabetes. Pain Physician 16:E71-E83

74. Jin HY, Liu WJ, Park JH, Baek HS, Park TS (2009) Effect of dipeptidyl peptidase-IV (DPP-IV) inhibitor (Vildagliptin) on peripheral nerves in streptozotocin-induced diabetic rats. Arch Med Res 40:536-544

75. Davidson EP, Coppey LJ, Dake B, Yorek MA (2011) Treatment of streptozotocin-induced diabetic rats with alogliptin: effect on vascular and neural complications. Exp Diabetes Res 2011:810469

76. Bianchi R, Cervellini I, Porretta-Serapiglia C et al (2012) Beneficial effects of p KF275-055, a novel, selective, orally bioavailable, long-acting dipeptidyl peptidase IV inhibitor in streptozotocininduced diabetic peripheral neuropathy. J Pharmacol Exp Ther $340: 64-72$
77. Tsuboi K, Mizukami H, Inaba W, Baba M, Yagihashi S (2016) The dipeptidyl peptidase IV inhibitor vildagliptin suppresses development of neuropathy in diabetic rodents: effects on peripheral sensory nerve function, structure and molecular changes. J Neurochem 136:859-870

78. Qi Y, Xu Z, Zhu Q et al (2013) Myocardial loss of IRS1 and IRS2 causes heart failure and is controlled by $\mathrm{p} 38 \alpha$ MAPK during insulin resistance. Diabetes 62:3887-3900

79. Nakamura M, Satoh N, Suzuki M et al (2015) Stimulatory effect of insulin on renal proximal tubule sodium transport is preserved in type 2 diabetes with nephropathy. Biochem Biophys Res Commun 461:154-158

80. Fornoni A, Rosenzweig SA, Lenz O, Rivera A, Striker GE, Elliot SJ (2006) Low insulin-like growth factor binding protein-2 expression is responsible for increased insulin receptor substrate-1 phosphorylation in mesangial cells from mice susceptible to glomerulosclerosis. Endocrinology 147:3547-3554

81. Myers MG Jr, Sun XJ, Cheatham B et al (1993) IRS-1 is a common element in insulin and insulin-like growth factor-I signaling to the phosphatidylinositol 3'-kinase. Endocrinology 132:1421-1430

82. Zheng Y, Yamada H, Sakamoto K et al (2005) Roles of insulin receptor substrates in insulin-induced stimulation of renal proximal bicarbonate absorption. J Am Soc Nephrol 16:2288-2295

83. Albert-Fort M, Hombrebueno JR, Pons-Vazquez S, Sanz-Gonzalez S, Diaz-Llopis M, Pinazo-Duran MD (2014) Retinal neurodegenerative changes in the adult insulin receptor substrate- 2 deficient mouse. Exp Eye Res 124C:1-10

84. Kern TS, Barber AJ (2008) Retinal ganglion cells in diabetes. J Physiol 586:4401-4408

85. Reiter $\mathrm{CE}, \mathrm{Wu} \mathrm{X}$, Sandirasegarane L et al (2006) Diabetes reduces basal retinal insulin receptor signaling: reversal with systemic and local insulin. Diabetes 55:1148-1156

86. Brussee V, Guo G, Dong Y et al (2008) Distal degenerative sensory neuropathy in a long-term type 2 diabetes rat model. Diabetes 57: 1664-1673

87. Rui L, Fisher TL, Thomas J, White MF (2001) Regulation of insulin/insulin-like growth factor-1 signaling by proteasomemediated degradation of insulin receptor substrate-2. J Biol Chem 276:40362-40367 